of cholera infantum and of focal sepsis-he was one of the first to recognize the relationship between infected teeth and arthritis-have become medical classics. Though many of his theories are to-day of historic interest and many of his therapeutic measures have been discarded, his title 'father of American psychiatry' is justified, for his 'Medical Inquiries and Observations upon the Diseases of the Mind", published the year before his death, was the first American text-book on psychiatry, and he was a pioneer in the humanitarian treatment of the insane and an early advocate of occupational therapy in asylums. A magnetic teacher, an elegant speaker and a felicitous writer, Benjamin Rush was a pronounced individualist, who made enemies as well as friends. He was one of the greatest 'bleeders' in the annals of medicine.

\section{The Good and the Clever}

Iт was a happy inspiration which caused the Master of Balliol to base his Memorial Lecture at Girton College, Cambridge, upon tho verses in which Miss Wordsworth referred to the possible antithesis between goodness and cleverness, when "the good are so harsh to the clever", and "the clever so rude to the good". He set out to show that nothing will make sense of the distinction, except to acknowledge that goodness is in its own way as rational as clevermess. "Let us begin with the Greeks," said he to his hearers, and then, as became his learning and his office, he took them through a fascinating journey from the Greeks on to the Renaissance, and thence to Rousseau, Kant and Bentham. Naturally, those of his hearers who had studied philosophy to some purpose must have got most out of this part of his discourse ; but none of them could have missed the heart of his theme, which was that "the really good man may not be learned or intellectual, but though he need not be clever he is not stupid. He has the imaginative power of putting himself in other people's places, and of going right past differences of rank and wealth and ability and all else, and getting to the essential human being". One remark will be of special interest to readers of this journal, devoted to science in its broadest interpretation. "Psychological classifications, case papers, and all the elaboration of card indices does help one to deal more effectively with people, but the most elaborate and scientific analysis misses out the authentic individual, just exactly what goodness should have the power of apprehending. If we only deal with people as specimens of this or that, sorted out in the most elaborate of ways . . . can we retain that reverence for the human personality as we meet it in ordinary men and women which is essential to any true service. . . Good and noble work has been done in that way, but not the best." It must have been a salutary experience for members of the particular audience addressed to be so effectively reminded that good men and women are sometimes also exceedingly wise, and that clever men and women ean sometimes also be exceedingly unwise.

\section{"Faraday's Encyclopedia of Hydrogen Compounds"}

THE scope of this important new aid to using chemical literature has already been explained in Nature (April 21, p. 467). Dr. Faraday and his publishers are to be congratulated on the fulfilment of their promise to keep it up to date by producing the first instalment of supplementary pages. This is no mean achievement in relation to the well-known difficulties of the moment with which printers and publishers are faced. The single sheets of the first replacement addition issue $\left(\mathbf{C}_{1}-\mathbf{C}_{5}\right)$ cover the year 1944 and bring the book up to January 1, 1945 (Chemindex, Ltd., Manchester 2. Pp. 64. 15s.). We know of no other book of reference in science which is in this happy position. On trial, it was found that the necessary work of changing the sheets and adding new ones took less than half an hour; the instructions given are so precise that any intelligent person can follow them. The new matter fits easily into the system and only three correction sheets were required, which is a testimony to the care taken in the original preparation. A leaflet enclosed with the sheets promises a second volume dealing with $\mathrm{C}_{6}$ and $\mathrm{C}_{7}$ shortly, while others are ready for the printer: we believe the practising organic chemist will be eager for these. It is of interest to note the degree to which the various abstract journals cover the published literature. A spot test of a random sample has shown that British Chemical Abstracts covered 27 per cent, American Chemical Abstracts 57 per cent and Chemisches Zentralblatt 70 per cent. On the basis of these figures, there seems room for improvement in Great Britain.

\section{Research Corporation Grants for Research}

Some 2,500,000 dollars is being offered in grants to educational institutions by the Research Corporation of New York, a non-profit organization devoted to advancing research and technology by the use of revenues from inventions assigned to it by publicspirited inventors. Preference in making these grants will be given, other factors being equal, to smaller institutions and those of more limited financial resources for research. The five-year programme announced by Dr. Joseph W. Barker, acting president, who is dean of engineering at Columbia University and until recently was a special assistant to the Secretary of the U.S. Navy, provides for one to two hundred grants of $2,500-5,000$ dollars a year to enable young men of science, engaged for the most part in war research in uniform or as civilians, to undertake at universities and colleges research of peacetime importance in pure science, especially chemistry, physics, mathematies and engineering. The first grants will be made shortly by a special committee of eminent men of science from industrial and university laboratories. Grants will be made to the institutions at which successful candidates will work and teach. The funds allotted will be available for the purchase of needed equipment and for the employment of assistants either as fellows or otherwise. Awards will be based primarily upon the demonstrated ability of the men who will conduct the researches and contribute to the teaching programme of the school. The grants are made possible by the fact that during the war years research programmes that would be normally supported by Research Corporation grants have been laid aside in order to free men and facilities for war research. The Research Corporation was begun in 1912 with the gift, through Dr. F. G. Cottrell, of patent rights on electrical precipitation, which is used for removing dust, fume and mists from industrial gases and from the atmosphere. From revenues derived from these and other patents it has made grants of $1,279,637$ dollars in past years to fifty-two institutions. In recent years the Corporation has served universities by administering inventions that may 